\title{
PENGARUH PEMBERIAN AIR SUSU IBU (ASI), KONSUMSI ZAT GIZI, DAN KELENGKAPAN KARTU MENUJ U SEHAT (KMS) TERHADAP STATUS GIZI BAYI
}

\author{
(The Effect of Breastfeeding, Nutrition Consumption, and Completeness of Healthy Card \\ on Infant Nutritional Status) \\ Suci Pujiyanti ${ }^{1}$ \\ ${ }^{1}$ Alumnus Program Studi Gizi Masyarakat dan Sumberdaya Keluarga, Fakultas Pertanian (FAPERTA) IPB.
Telp: 0251-8628304/8621258; Fax: 0251-8625846/8622276
}

\begin{abstract}
ABST RACT
Breastfeeding, nutrition consumption, and completeness of healthy card (KMS) are very crucial to support infant development. The objective of this research was to analyze the effect of breastfeeding, nutrition consumption, and completeness of healthy card to the nutritional status. Sample of babies who breastfed and having KMS were taken from 50 babies aged around 4-12 months using a simple random sampling method. Pearson corelation, Spearman corelation, and backward linear regression were used to analyze data. Linear regression analysis between the length of breastfeeding $(p<0.01)$ and sufficiency of protein level $(p \varangle 0.01)$ showed impact significantly to the infant nutritional status. The level energy sufficiency did not affect $(p>0.05)$ the infant nutritional status. The analysis also showed effect of weighing, immunization, and giving vitamin A to infant nutritional status.
\end{abstract}

Keywords: breastfeeding, nutrient consumption, healthy card

\section{PENDAHULUAN}

\section{Latar Belakang}

Sebuah keluarga yang lengkap adalah keluarga yang terdiri dari suami, istri, dan anak sebagai buah hati dari sebuah pernikahan. Kelahiran seorang bayi merupakan saat-saat yang paling menggembirakan bagi sepasang suami istri, akan tetapi sekaligus merupakan suatu amanah. Anak sebagai amanah tentunya harus dijaga, dirawat, dan dididik dengan sebaik-baiknya.

Zat gizi memiliki peranan yang sangat penting bagi kelangsungan tumbuh kembang anak dan kesehatannya. Zat gizi yang terbaik dan paling lengkap untuk bayi di kehidupan pertamanya adalah Air Susu Ibu (ASI) sampai dengan usia bayi 6 bulan. Komposisi ASI terdiri dari zat-zat gizi yang struktur dan kualitasnya sangat cocok untuk bayi dan mudah diserap oleh bayi. ASI juga mengandung zat antibodi yang berguna untuk melindungi bayi dari infeksi (Ramaiah, 2006).

Usia bayi yang lebih dari 6 bulan dapat diberikan MPASI secara bertahap mulai dari makanan yang lumat halus, lumat, lunak sampai dengan makanan padat. Saat disapih (usia 24 bulan) anak tersebut benar-benar bisa lepas dari konsumsi air susu ibunya dan digantikan dengan mengonsumsi makanan dan mi- numan yang gizinya seimbang untuk persiapan tumbuh kembang selanjutnya. Konsumsi yang seimbang terdiri dari makanan dan minuman yang di dalamnya mengandung karbohidrat, protein, lemak, vitamin, mineral, serta jumlahnya mencukupi kebutuhan tubuh individu.

Peran Posyandu (Pos Pelayanan Terpadu) tidak kalah pentingnya. Posyandu melakukan pemantauan pertumbuhan dan perkembangan anak melalui grafik berat badan dan mencatatnya pada KMS (Kartu Menuju Sehat). KMS juga berfungsi sebagai alat penyuluhan gizi kepada ibu-ibu yang memiliki anak balita (bawah lima tahun). KMS sebagai alat penyuluhan gizi menurut Mudjianto (2001) belum efektif. Ketidakefektifan ini terjadi karena masih rendahnya pemahaman kader posyandu dan ibu balita terhadap arti dari grafik pertumbuhan anak. Rendahnya pengetahuan kader untuk memberikan nasehat gizi kepada ibu balita ikut berpengaruh juga terhadap kekurangefektifan KMS. Selain itu, pesan-pesan gizi yang ada di dalam KMS seringkali tidak dimanfaatkan oleh ibu balita karena seringkali KMS disimpan pada kader dengan alasan takut hilang.

Berdasarkan hal-hal di atas, maka penulis merasa tertarik untuk melakukan penelitian tentang bagaimana pengaruh pemberian Air Susu Ibu (ASI), konsumsi gizi, dan kelengkapan Kartu Menuju Sehat (KMS) terhadap status gizi bayi. 


\section{$\underline{\text { Tujuan }}$}

Secara umum penelitian ini bertujuan untuk menganalisis pengaruh pemberian Air Susu Ibu (ASI), konsumsi gizi, dan kelengkapan Kartu Menuju Sehat (KMS) terhadap status gizi bayi. Tujuan khususnya adalah (1) menganalisis kelengkapan Kartu Menuju Sehat, konsumsi zat gizi, dan pemberian ASI, (2) menganalisis status gizi bayi, (3) menganalisis pengaruh pemberian ASI dan konsumsi gizi terhadap status gizi bayi, (4) menganalisis pengaruh kelengkapan KMS terhadap status gizi bayi.

\section{METODE}

\section{Desain, Tempat, dan Waktu Penelitian}

Desain penelitian ini adalah cross sectional study. Penelitian ini dilaksanakan di Kelurahan Kencana Kecamatan Tanah Sareal Kota Bogor dari bulan September 2007 sampai Januari 2008.

\section{Penarikan Contoh}

Contoh adalah bayi berusia 4-12 bulan dengan jumlah sebanyak 50 bayi yang diberikan ASI dan memiliki KMS. Penarikan contoh dengan cara simple random sampling.

\section{Łenis dan Cara Pengumpulan Data}

Data primer terdiri dari (1) karakteristik ibu, (2) karakteristik bayi, (3) status gizi bayi, (4) pengetahuan gizi ibu, dan (5) pola asuh kesehatan. Data primer diperoleh dari pengisian kuesioner oleh responden (ibu dari contoh). Data sekunder terdiri dari kelengkapan KMS serta data orang tua dan bayi di posyandu.

\section{Pengolahan dan Analisis Data}

Pengolahan dan analisis data dilakukan secara deskriftif dan inferensia dengan bantuan program Microsoft Excell dan SPSS for windows versi 13.0. Uji statistik yang digunakan adalah uji statistik korelasi Pearson dan uji statistik regresi linier metode backward. Uji statistik Pearson dan Spearman untuk melihat ada atau tidaknya hubungan yang erat antara karakteristik responden, karakteristik contoh, dan pengetahuan gizi responden terhadap pola asuh kesehatan (pemberian ASI, konsumsi, dan kelengkapan penimbangan) pada contoh. Sedangkan uji statistik regresi linier metode backward digunakan untuk melihat pengaruh pemberian ASI (lama pemberian ASI saja), konsumsi contoh (dilihat dari angka kecukupan energi dan protein), dan kelengkap- an KMS (dilihat dari kelengkapan penimbangan, kelengkapan imunisasi, dan pemberian vitamin A) terhadap status gizi contoh.

Soal pengetahuan gizi diberikan dalam bentuk pertanyaan correct answer multiple choice (Khomsan, 2000) sebanyak 19 pertanyaan, setiap pertanyaan bernilai 1 jika benar dan 0 jika salah atau tidak tahu. Nilai yang benar ditotalkan kemudian dibagi dengan angka 19, dikalikan $100 \%$ selanjutnya dikelompokkan ke dalam masing-masing kategori tingkat pengetahuan gizinya. Status gizi contoh diukur dengan menggunakan indeks $\mathrm{BB} / \mathrm{U}$ dengan cara Z-score dan diperoleh dua interpretasi.

Konsumsi anak melalui recall (Riyadi, 2001) 2 X 24 jam meliputi jenis makanan, jumlah makanan yang dikonsumsi dalam Ukuran Rumah Tangga (URT) atau dalam satuan gram (disamakan dalam satuan gram). Jumlah konsumsi pangan dihitung kandungan gizinya menggunakan Daftar Konsumsi Bahan Makanan (DKBM) dan label makanan bersangkutan (untuk makanan yang belum ada di DKBM).

Hasil yang didapat dari perhitungan tersebut kemudian dibandingkan dengan konsumsi gizi aktual (AKGaktual / AKGJ * 100 \%), kemudian hasilnya dikategorikan menjadi tingkat kecukupan gizi (energi dan protein) baik dan kurang.

Kelengkapan KMS dilihat dari kurva berat badan (penimbangan contoh), kelengkapan imunisasi, dan pemberian kapsul vitamin A. Kelengkapan penimbangan dilihat dari frekuensi contoh ditimbang dibandingkan dengan usianya. Kelengkapan imunisasi dilihat dari frekuensi masing-masing imunisasi yang dianjurkan dibandingkan dengan usianya. Sedangkan pemberian vitamin A dilihat dari ketepatan pemberiannya sesuai dengan usia contoh.

\section{HASIL DAN PEMBAHASAN}

\section{Pola Asuh Kesehatan}

\section{Pemberian ASI}

Berdasarkan Tabel 1, sebesar 88\% contoh masih diberikan ASI (ASI saja dan ASI yang didampingi MPASI). Dari 88\% contoh yang masih diberikan ASI, hanya sebesar $34 \%$ yang mendapatkan ASI eksklusif. Sebesar $12 \%$ contoh sudah tidak diberikan ASI melainkan diberikan pengganti ASI (Tabel 1). Jadwal pemberian ASI berbeda pada setiap responden, $73 \%$ responden memberikan ASI jika anak menangis, 20\% responden memberikan ASI jika anak meminta, 
dan $7 \%$ responden memberikan ASI setiap saat (Tabel 1).

Lama waktu menyusui pada contoh berkisar antara satu menit sampai dengan satu jam (rata-rata menyusui 15-16 menit). Berdasarkan Tabel 1 sebanyak 73\% contoh menyusu selama $\leq 15$ menit.

Tabel 1. Sebaran Contoh berdasarkan Pemberian ASI

\begin{tabular}{ccc}
\hline Pemberian ASI & N & $\mathbf{\%}$ \\
\hline Tidak & 6 & 12 \\
Ya, masih diberikan & 44 & 88 \\
Total & $\mathbf{5 0}$ & $\mathbf{1 0 0}$ \\
\hline J adwal pemberian ASI & $\mathbf{N}$ & $\mathbf{\%}$ \\
\hline Tiap menangis & 32 & 73 \\
Tiap meminta & 9 & 20 \\
Tiap saat & 3 & 7 \\
Total & $\mathbf{4 4}$ & $\mathbf{1 0 0}$ \\
\hline Lama waktu menyusui & $\mathbf{N}$ & $\%$ \\
\hline 15 menit & 32 & 73 \\
$>$ 15 menit & 12 & 27 \\
Total & $\mathbf{4 4}$ & $\mathbf{1 0 0}$ \\
\hline
\end{tabular}

Lamanya menyusu pada hari-hari pertama bayi baru lahir biasanya selama 4-5 menit karena ASI belum banyak yang keluar. Menyusu pada hari-hari pertama kelahiran dimaksudkan untuk merangsang produksi ASI dan membiasakan puting susu dihisap oleh bayi. Bayi boleh disusukan selama 10 menit setelah bayi berusia 4-5 hari dan setelah ASI yang diproduksi banyak, bayi dapat disusukan selama 15 menit (Soetjiningsih, 1997).

\section{Konsumsi gizi}

Hasil penelitian (Tabel 2) menunjukkan bahwa sebagian besar (98\%) TKE contoh dan sebesar 76\% TKP contoh termasuk kategori cukup. Akan tetapi masih adapula yang TKE (2\%) dan TKP (24\%) nya masih kurang dari $70 \%$. Walaupun jumlahnya lebih sedikit dari contoh yang termasuk kategori cukup TKE dan TKP nya, jika hal ini dibiarkan terus menerus akan terjadi keterlambatan pertumbuhan terutama berat badan dan tinggi badan, serta mempengaruhi tingkat kecerdasan (Amelia, 2004).

Tabel 2. Sebaran Contoh berdasarkan Tingkat Kecukupan Gizinya

\begin{tabular}{|c|c|c|}
\hline Tingkat kecukupan zat gizi & $\mathbf{N}$ & $\%$ \\
\hline \multicolumn{3}{|l|}{ Energi: } \\
\hline$<70 \%$ & 1 & 2 \\
\hline$>70 \%$ & 49 & 98 \\
\hline \multicolumn{3}{|l|}{ Protein: } \\
\hline$<70 \%$ & 12 & 24 \\
\hline$>70 \%$ & 38 & 76 \\
\hline
\end{tabular}

Zat gizi (energi dan protein) yang dibutuhkan seseorang bergantung kepada aktifitas dan tingkat kesehatannya. Semakin banyak aktifitas seseorang maka dibutuhkan energi yang lebih tinggi. Begitupun dengan orang yang sedang di dalam masa penyembuhan membutuhkan lebih banyak zat gizi untuk mempercepat proses penyembuhannya. Maka dari itu asupan konsumsi yang baik harus didukung pula oleh keadaan tubuh yang sehat (bebas dari infeksi dan penyakit lainnya) agar penyerapan zat gizi di dalam tubuh optimal.

Uji korelasi Spearman menunjukkan bahwa tingkat kecukupan energi $\left(r_{\mathrm{s}}=-0.359^{*}\right.$, $\mathrm{p}=0.011)$ dan protein $\left(\mathrm{r}_{\mathrm{s}}=-0.517^{* *}, \mathrm{p}=0.000\right)$ berhubungan negatif dengan masih atau tidaknya ASI diberikan. Hal ini menunjukkan bahwa contoh yang sudah tidak diberikan ASI tingkat kecukupan energi dan proteinnya lebih tinggi daripada yang masih diberikan ASI. Keadaan ini bisa terjadi karena contoh yang sudah tidak diberikan ASI lebih banyak mengonsumsi susu formula yang energinya lebih tinggi dari ASI per 100 gramnya.

\section{Kelengkapan Kartu Menuju Sehat (KMS)}

\section{Penimbangan}

Berdasarkan Tabel 3 sebanyak 52\% contoh kelompok usia $\leq 6$ bulan memiliki kelengkapan penimbangan yang lebih lengkap dibandingkan dengan kelompok usia > 6 bulan. Sebanyak $62 \%$ contoh kelompok usia > 6 bulan memiliki kelengkapan penimbangan yang termasuk kategori tidak lengkap.

Tabel 3. Sebaran Contoh berdasarkan Kelengkapan penimbangannya

\begin{tabular}{ccccc}
\hline \multirow{2}{*}{$\begin{array}{c}\text { Kategori usia } \\
\text { contoh }\end{array}$} & \multicolumn{2}{c}{ Tidak lengkap } & \multicolumn{2}{c}{ Lengkap } \\
\cline { 2 - 5 } & $\mathbf{n}$ & $\%$ & $\mathbf{n}$ & $\%$ \\
\hline$\leq 6$ bulan & 8 & 38 & 15 & 52 \\
$>$ 6 bulan & 13 & 62 & 14 & 48 \\
Total & $\mathbf{2 1}$ & $\mathbf{1 0 0}$ & $\mathbf{2 9}$ & $\mathbf{1 0 0}$ \\
\hline
\end{tabular}

Kesehatan seorang anak dapat dilihat dari beberapa hal, khususnya untuk anak usia 0-5 tahun kesehatan anak dapat dilihat dari berat badannya setiap bulan melalui KMS (Kartu Menuju Sehat). Menurut Mudjianto (2001), KMS adalah alat yang digunakan untuk mencatat dan mengamati kesehatan anak melalui berat badannya dari bulan ke bulan khususnya anak usia 0-5 tahun.

\section{Imunisasi BCG}

Berdasarkan penelitian, $100 \%$ contoh telah mendapatkan imunisasi BCG dengan leng- 
kap. Imunisasi BCG (Bacille Calmette Geurin) adalah imunisasi untuk mencegah penyakit tuberkolosis atau lebih dikenal dengan penyakit TBC yang disebabkan oleh bakteri berbentuk batang Mycobacterium tubercolosis atau Basil Tahan Asam (BTA). Secara teori bakteri ini bisa menyerang tulang, selaput otak, usus, dan kelenjar getah bening (Achmadi, 2006).

\section{Imunisasi Hepatitis B}

Berdasarkan penelitian, sebanyak $87 \%$ contoh kelompok usia $\leq 6$ bulan dan $81 \%$ contoh kelompok usia yang $>6$ bulan telah mendapatkan imunisasi hepatitis $B$ dengan lengkap. Imunisasi hepatitis B diberikan untuk mencegah penyakit hepatitis B. Hepatitis B adalah peradangan hati atau liver kronik hingga akut. Pada keadaan yang parah dapat menimbulkan kanker dan pengerasan hati.

\section{Imunisasi Polio}

Berdasarkan penelitian, sebanyak $52 \%$ contoh kelompok usia $\leq 6$ bulan dan sebanyak $59 \%$ contoh kelompok usia > 6 bulan telah mendapatkan imunisasi polio sebanyak 4 kali. Imunisasi polio diberikan untuk mencegah penyakit polio karena virus yang menyebabkan kelumpuhan kaki (kelumpuhan tanpa kehilangan alat perasa). Virus polio masuk ke dalam tubuh melalui pencernaan.

\section{Imunisasi DPT}

Berdasarkan penelitian, sebanyak $57 \%$ contoh kelompok usia $\leq 6$ bulan dan sebanyak $63 \%$ contoh kelompok usia > 6 bulan telah mendapatkan imunisasi DPT sebanyak 3 kali. Imunisasi DPT diberikan untuk mencegah penyakit difteri, polio, dan tetanus.

\section{Imunisasi Campak}

Pemberian imunisasi campak yang dianjurkan Ikatan Dokter Anak Indonesia adalah sebanyak 2 kali. Imunisasi pertama diberikan pada usia 9 bulan dan imunisasi kedua pada usia 6 tahun. Dalam penelitian ini ditemukan adanya pemberian imunisasi campak pada $9 \%$ contoh usia $\leq 6$ bulan, hal itu menurut keterangan bidan tidak apa-apa, asalkan imunisasi sebelumnya sudah lengkap, akan tetapi jika dibandingkan dengan anjuran di atas tentu tidak sesuai. Selain itu, hanya $26 \%$ contoh kelompok usia > 6 bulan telah mendapatkan 1 kali imunisasi campak.

\section{Pemberian Suplemen Vitamin A}

Pemberian vitamin A pada contoh yang > 6 bulan baru sebesar 44\%, hal ini dikarenakan contoh yang lainnya yang belum mendapat vitamin A pada kelompok usia > 6 bulan (56\%) belum genap berusia 6 bulan disaat bulan vitamin A. Sedangkan sebesar $4 \%$ contoh kelompok usia $\leq 6$ bulan ada yang telah mendapatkan vitamin A, karena usianya genap 6 bulan bertepatan dengan pemberian vitamin $\mathrm{A}$ di posyandu.

\section{KESIMPULAN}

Sebanyak $52 \%$ contoh usia $\leq 6$ bulan memiliki kelengkapan penimbangan yang lengkap. Sebanyak 100\% contoh telah mendapatkan imunisasi BCG lengkap. Sebanyak $87 \%$ contoh usia $\leq 6$ bulan dan $81 \%$ contoh usia $>6$ bulan telah mendapatkan imunisasi hepatitis B lengkap. Sebanyak 52\% contoh kelompok usia $\leq 6$ bulan dan sebanyak $59 \%$ contoh kelompok usia $>6$ bulan telah mendapatkan imunisasi polio sebanyak 4 kali. Sebanyak $57 \%$ contoh usia $\leq 6$ bulan dan 63\% contoh usia > 6 bulan telah mendapatkan imunisasi DPT 3 kali. Sebesar $26 \%$ contoh usia $>6$ bulan telah mendapatkan 1 kali imunisasi campak. Sebesar $44 \%$ contoh usia > 6 bulan telah mendapatkan vitamin A satu kali. Sebesar $98 \%$ contoh memiliki (TKE) > $70 \%$ dan sebesar $76 \%$ contoh memiliki TKP > 70\%. Sebesar $88 \%$ contoh masih diberikan ASI (ASI saja dan ASI yang didampingi MPASI). Dari $88 \%$ contoh yang masih diberikan ASI, hanya sebesar 34\% yang mendapatkan ASI eksklusif.

Sebagian besar (95\%) contoh memiliki status gizi yang baik. Pemberian ASI dan TKP berpengaruh terhadap status gizi contoh.

Kelengkapan penimbangan, kelengkapan imunisasi (imunisasi hepatitis $B$, imunisasi DPT1, dan imunisasi campak) dan pemberian vitamin A berpengaruh terhadap status gizi contoh.

\section{DAFTAR PUSTAKA}

Achmadi UF. 2006. Imunisasi Mengapa Perlu. Buku Kompas, Jakarta

Amelia I. 2004. Pola Pemberian Makan dan Status Gizi Anak di Bawah Dua Tahun (BADUTA) di Pedesaan dan Perkotaan Kabupaten Kuningan Propinsi Jawa Barat. Skripsi Sarjana Departemen Gizi Masyarakat dan Sumberdaya Keluarga, Fakultas Pertanian, IPB, Bogor.

Khomsan A. 2000. Teknik Pengukuran Pengetahuan Gizi. Jurusan Gizi Masyarakat dan 
Sumberdaya Keluarga, Fakultas Pertanian, IPB, Bogor.

Mudjianto T. 2001. Efektifitas Kartu Menuju Sehat (KMS) Anak Balita Sebagai Sarana Penyuluhan Gizi di Posyandu. Laporan Penelitian Departemen Kesehatan Republik Indonesia, Badan Penelitian dan Pengembangan Kesehatan, Badan Penelitian dan Pengembangan Gizi dan Makanan, Bogor.
Ramaiah S. 2006. ASI dan Menyusui. Buana Ilmu Populer, Jakarta.

Riyadi H. 2001. Metode Penilaian Status Gizi Secara Antropometri. Jurusan Gizi Masyarakat dan Sumberdaya Keluarga, Fakultas Pertanian, IPB, Bogor.

Soetjiningsih. 1997. ASI: Petunjuk untuk Tenaga Kesehatan. Buku Kedokteran EGC, Jakarta. 